\title{
The Effect of Mineral and Organic Fertilization on Common Osier (Salix viminalis L.) Productivity and Qualitative Parameters of Naturally Acidic Retisol
}

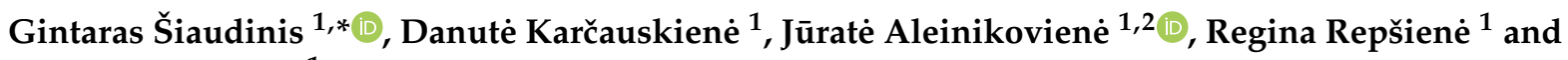 \\ Regina Skuodiené ${ }^{1}$ \\ 1 Vèžaičiai Branch of the Lithuanian Research Centre for Agriculture and Forestry, Gargždu 29, \\ 96216 Klaipėda distr., Vèžaičiai, Lithuania; danute.karcauskiene@lammc.lt (D.K.); \\ jurate.aleinikoviene@vdu.lt (J.A.); regina.repsiene@lammc.lt (R.R.); regina.skuodiene@lammc.lt (R.S.) \\ 2 Institute of Agroecosystems and Soil Science, Vytautas Magnus University Agriculture Academy, \\ Studentu 11, LT-53362 Kaunas distr., Akademija, Lithuania \\ * Correspondence: gintaras.siaudinis@lammc.lt
}

Citation: Šiaudinis, G.;

Karčauskienè, D.; Aleinikovienè, J.;

Repšienè, R.; Skuodienè, R. The Effect

of Mineral and Organic Fertilization

on Common Osier (Salix viminalis L.)

Productivity and Qualitative

Parameters of Naturally Acidic

Retisol. Agriculture 2021, 11, 42.

https://doi.org/10.3390/agriculture 11010042

Received: 9 November 2020

Accepted: 7 January 2021

Published: 9 January 2021

\begin{abstract}
One of the potential options for sewage sludge as an alternative organic material is the fertilization of energy crops. To evaluate the effect of granulated sewage sludge and mineral fertilization N60P60K60 on common osier's (Salix viminalis L.) biomass productivity and soil parameters, field trials were held in Western Lithuania's naturally acidic Retisol (WB 2014; $\mathrm{pH}_{\mathrm{KCl}}$ 4.35-4.58). After four years of cultivation and dependent on fertilization type, common osier dry matter (DM) yield varied from 49.60 to $77.92 \mathrm{t} \mathrm{ha}^{-1}$. Higher DM yield was related to an increased number of stems/plants. The application of a $90 \mathrm{t} \mathrm{ha}^{-1}$ sewage sludge rate had a significant and positive impact on common osier productivity, as well as on the increment of soil organic carbon, total $\mathrm{N}$, and mobile $\mathrm{P}_{2} \mathrm{O}_{5}$ content in the upper 0-30 cm soil layer. The use of both sewage sludge rates ( 45 and $\left.90 \mathrm{tha}^{-1}\right)$ had a similar impact on soil bulk density, water-stable aggregates, and the active soil microbial biomass. Annual mineral fertilization had little effect on the parameters studied. When growing common osier in Retisol, $45 \mathrm{t} \mathrm{ha}^{-1}$ of a single sewage sludge rate was enough to maintain both plant and soil productivity.
\end{abstract}

Keywords: common osier; fertilization; dry matter yield; soil chemical parameters; soil bulk density; water-stable aggregates; soil microbial carbon

\section{Introduction}

Sludge is a byproduct of domestic or industrial wastewater treatments. Recycling sewage sludge has remained a significant problem in many countries worldwide [1-4]. By containing a high concentration of organic carbon, nitrogen, phosphorus, and other nutrients, sewage sludge serves as a good organic matter source for plants, either providing the soil with beneficial physical and microbial properties [5-7]. As a sewage sludge substrate is of organic origin, the use of the substrate might maintain soil productivity for several consecutive years. Börjesson and Kätterer point out that the application of $12 \mathrm{t} \mathrm{ha}^{-1}$ sewage sludge every four years represents a valuable resource for improving soil fertility vis-à-vis soil organic matter and soil structure; however, its efficiency for nutrient (particularly phosphorus, nitrogen) cycling is very low within this timeframe [8]. Most improvement for the soil aggregate stability is associated with an increase in soil organic carbon content $[9,10]$. However, other sewage sludge constituents (e.g., heavy metals, pathogens) could be harmful to the environment and human health [11].

According to Polish research, the cultivation of willow on soil treated with 3 and $9 \mathrm{t} \mathrm{ha}^{-1}$ sewage sludge results in a gradual increase of humus fractions, total organic carbon content, and bacterial abundance, and a large increase of willow biomass. Organic 
compounds and high content of sewage sludge nutrients activate soil microbial activity [12]. Low rates of sewage sludge increase soil microbial activity; however, some other research indicates that the excessive application of sewage sludge can cause the accumulation of both organic and inorganic pollutants, which may cause a negative effect on the soil ecosystem [13,14]. It is important to keep in mind that the application of sewage sludge can also result in environmental problems. Apart from organic content and nutrients, sludge also includes toxic compounds, heavy metals, dissolved inorganic salts, chlorinated lignin, and phenolic derivatives $[15,16]$. The application of sewage sludge can cause a negative ecological impact on terrestrial ecosystems and pose a human health risk [11,17]. For this reason, the use of sewage sludge as an organic fertilizer is limited in many countries worldwide $[2,5,18]$.

Since sewage sludge contains unwanted pollutants, its utilization for traditional crop fertilization is problematic. Yet, to reduce cultivation costs, sewage sludge might be an appropriate alternative fertilizer for energy crops. Many authors have noted that to avoid competition with traditional food crops, energy crops (as well as other non-food crops) should be grown in less productive soils, polluted soils, brownfields, marginal, set-aside, and abandoned lands, all of which might be appropriate for energy crop cultivation [19-22]. For example, Retisols and Fluvisols are typically found in Western Lithuania. However, due to these soils' high acidity and worsening physical, chemical, and microbial properties, traditional farming is often unprofitable [23]. With increased biomass being used for alternative energy purposes, a share of such fertile land could be assigned for energy crop cultivation.

Salix species are fast-growing and high-yielding; therefore, they can be widely cultivated worldwide. Many studies have assessed the impact of sewage sludge on both common osier (Salix viminalis L.) productivity and qualitative indicators [24,25]. However, before our field experiment, we found scarce information on how a common osier (Salix viminalis L.) is suitable for cultivation in highly acidic Retisol and how sewage sludge affects soil parameters in the common osier growing site.

By executing the experiment, we set a goal complex to evaluate the impact of single sewage sludge on Salix viminalis productivity, and changes of soil chemical, physical, and microbial properties of acid moraine loam soil in Retisol.

\section{Materials and Methods}

\subsection{Location of the Experimental Site}

The experiment with an energy crop common osier (Salix viminalis L.) was established at the Vezžaičiai Branch of the Lithuanian Research Centre for Agriculture and Forestry. The site was located at the eastern edge of a seaside lowland area (Western Lithuania, $55^{\circ} 43^{\prime} \mathrm{N}$, $\left.21^{\circ} 27^{\prime} \mathrm{E}\right)$.

\subsection{Soil Characteristics}

The soil type was a naturally acid moraine loam Bathygleyic Dystric Glossic Retisol (WRB 2014). The following soil chemical parameters (in upper soil layer) were evaluated prior to the experiment: $\mathrm{pH}_{\mathrm{KCl}}$ was $4.27-4.59$, mobile aluminum was $13.69-34.21 \mathrm{mg} \mathrm{kg}^{-1}$, total nitrogen was $0.11-0.12 \%$, total carbon was $1.19-1.25 \%$, mobile $\mathrm{P}_{2} \mathrm{O}_{5}$ was $50.3-68.3 \mathrm{mg} \mathrm{kg}^{-1}$, and mobile $\mathrm{K}_{2} \mathrm{O}$ was $251-303 \mathrm{mg} \mathrm{kg}^{-1}$.

\subsection{Mineral Fertilizers and Granulated Sewage Sludge}

Mineral fertilizers. The annual application rates for nitrogen, phosphorus and potassium were equal: $60 \mathrm{~kg} \mathrm{ha}^{-1} \mathrm{~N}, \mathrm{P}_{2} \mathrm{O}_{5}$, and $\mathrm{K}_{2} \mathrm{O}$ (N60P60K60) (in active ingredient).

Sewage sludge. The chemical composition of the granulated sewage sludge was as follows: $\mathrm{pH}-5.56$, total nitrogen-33.4 $\mathrm{g} \mathrm{kg}^{-1}$, total phosphorus- $5.02 \mathrm{~g} \mathrm{~kg}^{-1}$, total potassium-2.80 $\mathrm{g} \mathrm{kg}^{-1}$, organic matter- $64.97 \%$. The sewage sludge contained the following heavy metals concentrations: lead (Pb) $-14.47 \mathrm{mg} \mathrm{kg}^{-1}$, cadmium (Cd) $-0.44 \mathrm{mg} \mathrm{kg}^{-1}$, 
chromium $(\mathrm{Cr})-11.51 \mathrm{mg} \mathrm{kg}^{-1}$, copper $(\mathrm{Cu})-47.8 \mathrm{mg} \mathrm{kg}^{-1}$, nickel (Ni)—8.22 $\mathrm{mg} \mathrm{kg}^{-1}$, zinc ( $\mathrm{Zn})-287 \mathrm{mg} \mathrm{kg}^{-1}$, and mercury ( $\left.\mathrm{Hg}\right)-0.96 \mathrm{mg} \mathrm{kg}^{-1}$.

Using $45 \mathrm{t} \mathrm{ha}^{-1}$ sewage sludge rate, the following amounts of nutrients were inserted into the soil: $1503 \mathrm{~kg}$ of total nitrogen, $230 \mathrm{~kg}$ of total phosphorus, and $126 \mathrm{~kg}$ of total potassium. Accordingly, by the use of $90 \mathrm{t} \mathrm{ha}^{-1}$ sewage sludge rate, $3006 \mathrm{~kg}$ of total nitrogen, $460 \mathrm{~kg}$ of total phosphorus, and $252 \mathrm{~kg}$ of total potassium were inserted into the soil.

\subsection{Experimental Design}

Field research began in 2013. Common osier's (cv. "Tordis") cuttings of about $0.30 \mathrm{~m}$ long were planted in the soil on 5 May 2013. Each treatment was composed of two parallel $10 \mathrm{~m}$ long rows. The distance between the rows was $0.75 \mathrm{~m}$, the distance between each plant was $0.50 \mathrm{~m}$, the distance between the rows of different treatments was $1.25 \mathrm{~m}$. Next year, i.e., on 23 April 2014, to increase the branching ability, common osier's stems were cut at $\sim 5 \mathrm{~cm}$ height. The weight of the first-year stems was not calculated.

The experiment was composed of four treatments: (1) Control (not fertilized); (2) N60P60K60 (mineral fertilization) (in active ingredient); (3) $45 \mathrm{t} \mathrm{ha}^{-1}$, and (4) $90 \mathrm{tha}^{-1}$ sewage sludge rates. All four treatments were randomly allocated. The number of replications -3 . The fertilization of granulated sewage sludge was done once in the 2nd growing year (on 6 May 2014). The granules were immediately inserted into the soil by tillage implements. NPK fertilization was done each year at the beginning of spring vegetation.

\subsection{Sampling and Analytical Methods}

Common osier yield was harvested after four years of cultivation (2014-2017) on 19 September 2017. The following structural parameters were evaluated: the number of stems per plant stems height, and biomass yield. To evaluate these parameters, five typical plants were chosen from each treatment from all three replications. The common osier dry mass (DM) mass yield was measured by drying plant samples at $105{ }^{\circ} \mathrm{C}$ to the constant weight. Dried plant samples were weighed and recalculated into dry matter (DM) yield $\left(\mathrm{t} \mathrm{ha}^{-1}\right)$.

Soil chemical analyses at the growing site of common osiers were done in 2013 (at the beginning of the experiment) and 2016 (in the 3rd experimental year). In both cases, soil samples (in 0-30 $\mathrm{cm}$ upper soil layer) were taken in October. The following parameters were evaluated: $\mathrm{pH}_{\mathrm{KCl}}$ was measured by a potentiometric method in $1 \mathrm{M} \mathrm{KCl}(1: 2.5, w / v)$ extract (ISO 10390:2005); organic C ( $\left.C_{\text {org }}\right)$ content-by a spectrophotometric measurement at $590 \mathrm{~nm}$ after dichromatic oxidation using glucose as a standard (ISO 10694:1995), total $\mathrm{N}\left(\mathrm{N}_{\text {tot }}\right)$ content-by the Kjeldahl method (ISO 11261-1995), mobile $\mathrm{P}_{2} \mathrm{O}_{5}$, and $\mathrm{K}_{2} \mathrm{O}$ contents-by extraction (A-L) method (both by LVP D-07:2016).

Soil samples for soil physical analysis were taken from the topsoil in 2015 and 2017. Soil samples for soil physical analysis were taken from the topsoil in 2015 and 2017. Dry aggregates size distribution was determined by the standard dry and wet sieving Savinov method [26]. Briefly, $1000 \mathrm{~g}$ of air-dried, soil sample is sieved through a nest of sieves having $10,5,3,2,1,0.5$, and $0.25 \mathrm{~mm}$ square openings so eight aggregate size classes are obtained $(>10,10-5,5-3,3-2,2-1,1-0.5,0.5-0.25$, and $<0.25 \mathrm{~mm}$. The soil of each aggregate size classes is weighed separately, and the percentage of the fraction is calculated from the total soil weight. A sample of $50 \mathrm{~g}$ is taken from the aggregate fractions in proportion to their percentage composition for wet sieving analysis. By the wet sieving procedure 6 classes were separated $>3,3-2,2-1,1-0.5,0.5-0.25$, and $<0.25 \mathrm{~mm}$. The soil bulk density $\left(100 \mathrm{~cm}^{3}\right)$ was estimated according to the Kachinsky method. Soil moisture content was measured by the weighting method.

Soil samples for microbial analysis were taken twice per 2014-2016 in spring and autumn for three treatments (Control, $45 \mathrm{tha}^{-1}$, and $90 \mathrm{tha}^{-1}$ sewage sludge) in 0-30 cm 
upper soil layer. The chloroform fumigation-extraction (CFE) method was used to evaluate soil microbial biomass carbon $\left(\mu \mathrm{g} \mathrm{g}^{-1} \mathrm{C}\right)$ [27].

\subsection{Statistical Analysis}

To evaluate the significance of the obtained biomass productive parameters (i.e., number of stems/plants, stems height, stems diameter, and dry mass yield), a one-way statistical analysis was performed on the fertilization rate, using analysis of variance (ANOVA) at $L S D_{05}$ and $L S D_{01}$ (95\% and $99 \%$ probability levels).

\section{Results}

\subsection{Common Osier Yield and Structure}

The biometric parameters for the common osier yield are presented in Table 1. Biomass yield was harvested after 4 years of cultivation.

Table 1. The structural parameters of the common osier's yield after 4 years of cultivation.

\begin{tabular}{ccccc}
\hline Treatments & $\begin{array}{c}\text { Number of } \\
\text { Stems/Plants }\end{array}$ & $\begin{array}{c}\text { Stems Height, } \\
\mathbf{c m}\end{array}$ & $\begin{array}{c}\text { Stems } \\
\text { Diameter, } \mathbf{m m}\end{array}$ & $\begin{array}{c}\text { DM Yield, } \\
\mathbf{t ~ h a}^{-\mathbf{1}}\end{array}$ \\
\hline Control & 2.34 & 567 & 29.98 & 49.60 \\
\hline N60P60K60 & 2.80 & 552 & 29.12 & 52.00 \\
\hline $\begin{array}{c}45 \mathrm{t} \mathrm{ha}^{-1} \text { sewage } \\
\text { sludge }\end{array}$ & 2.87 & 554 & 30.80 & $65.68^{* *}$ \\
\hline $\begin{array}{c}90 \mathrm{t} \mathrm{ha}^{-1} \text { sewage } \\
\text { sludge }\end{array}$ & $3.47^{*}$ & 528 & 31.60 & $77.92^{* *}$ \\
\hline LSD $_{05 / 01}$ & $1.12 / \mathrm{ns}$ & $\mathrm{ns} / \mathrm{ns}$ & $\mathrm{ns} / \mathrm{ns}$ & $6.90 / 10.45$ \\
\hline
\end{tabular}

**** significant at $95 \%$ and $99 \%$ probability levels, respectively; ns-not significant.

In comparison with the unfertilized plot (in control treatment), fertilizing $90 \mathrm{tha}^{-1}$ of sewage sludge caused the number of stems/plants too, on average, increase to 3.47. Irrespective of fertilization type, the stem height varied from 528 to $567 \mathrm{~cm}$. The use of sewage sludge also increased stem diameter, though the increment was not statistically substantial. Both (45 and $90 \mathrm{t} \mathrm{ha}^{-1}$ ) sewage sludge rates increased total dry matter (DM) yield (accumulated per 4 growing years) to 65.68 and $77.92 \mathrm{t} \mathrm{ha}^{-1}$, respectively (significant at $99 \%$ probability level). Thus, compared to the control treatment (when growing without fertilization), DM yield increased by $32.4-57.1 \%$. There was a positive average correlation $(+0.66)$ between the number of stems/plants and DM yield: $\mathrm{Y}_{(\mathrm{DM} \text { yield })}=24.67+$ $0.0008 \mathrm{x}_{\text {(number of stems/plants) }}$. The other two parameters had a weak correlation with DM yield.

It should be noted that the annual use of mineral NPK fertilizers had a weak impact on common osier's DM yield; the increase was not significant. Earlier studies in Sweden showed that nitrogen fertilizers had a positive effect on common osier's yield during the 2nd and 3rd growing years [28].

\subsection{Soil Chemical Properties}

During the experimental years, soil $\mathrm{pH}_{\mathrm{KCl}}$ values remained substantially unchanged (Table 2). In 2013, the average soil $\mathrm{pH}$ in the common osier's growing site was $4.40 \pm 0.16$. After three experimental years (in September 2016), irrespective of fertilization type, soil $\mathrm{pH}_{\mathrm{KCl}}$ varied from 4.41 to 4.49 . Thus, the application of sewage sludge had no impact on soil acidity level. 
Table 2. Soil chemical content at the growing site of a common osier, specifically for the $0-30 \mathrm{~cm}$ upper soil layer (2013 and 2016).

\begin{tabular}{|c|c|c|c|c|c|c|}
\hline \multirow[b]{2}{*}{ Treatments } & \multirow[b]{2}{*}{$\mathrm{pH}_{\mathrm{KCl}}$} & \multirow{2}{*}{$\begin{array}{c}\text { Organic } \\
\text { C (\%) }\end{array}$} & \multirow{2}{*}{$\begin{array}{l}\text { Total } \\
\text { N (\%) }\end{array}$} & \multirow[b]{2}{*}{$\mathrm{C}_{\text {org }}: \mathrm{N}_{\text {tot }}$} & \multicolumn{2}{|c|}{ Mobile } \\
\hline & & & & & $\begin{array}{c}\mathrm{P}_{2} \mathrm{O}_{5} \\
\left(\mathrm{mg} \mathrm{kg}^{-1}\right)\end{array}$ & $\begin{array}{c}\mathrm{K}_{2} \mathrm{O} \\
\left(\mathrm{mg} \mathrm{kg}^{-1}\right)\end{array}$ \\
\hline \multicolumn{7}{|c|}{2013 (before the experiment) } \\
\hline & $4.40 \pm 0.16$ & $1.18 \pm 0.06$ & $0.07 \pm 0.01$ & $16.51 \pm 0.98$ & $59.3 \pm 13.6$ & $277 \pm 0.02$ \\
\hline \multicolumn{7}{|c|}{2016} \\
\hline Control & 4.44 & 1.16 & 0.07 & 15.69 & 69.4 & 296 \\
\hline $\begin{array}{c}45 \mathrm{t} \mathrm{ha}^{-1} \\
\text { sewage } \\
\text { sludge }\end{array}$ & 4.41 & 1.34 * & $0.09 *$ & 14.92 & 332 & 226 \\
\hline $\begin{array}{c}90 \text { t ha }^{-1} \\
\text { sewage } \\
\text { sludge }\end{array}$ & 4.49 & $1.52 * *$ & $0.11^{* *}$ & $13.74^{*}$ & 816 & 251 \\
\hline $\mathrm{LSD}_{05 / 01}$ & $\mathrm{~ns} / \mathrm{ns}$ & $0.15 / 0.23$ & $0.02 / 0.03$ & $2.71 / \mathrm{ns}$ & $146 / 222$ & $\mathrm{~ns} / \mathrm{ns}$ \\
\hline
\end{tabular}

*,** significant at $95 \%$ and $99 \%$ probability levels, respectively; ns-not significant.

In 2013, the average organic $C\left(C_{\text {org }}\right)$ content in the topsoil layer was $1.18 \pm 0.06 \%$. Over three years of research, the application of 45 and $90 \mathrm{tha}^{-1}$ sewage sludge rates caused a substantial increase of organic C content (at $95 \%$ and $99 \%$ probability levels, respectively).

Before the experiment, the average $\mathrm{N}_{\text {tot }}$ content was $0.07 \pm 0.01 \%$. The application of both sewage sludge rates significantly increased $\mathrm{N}_{\text {tot }}$ content to $0.09-0.11 \%$ (at $99 \%$ probability level). In the control treatment, even though the common osier utilized high amounts of $\mathrm{N}$ for biomass accumulation, the total $\mathrm{N}$ content in the topsoil did not significantly change throughout the experimental period.

The application of both sewage sludge rates decreased $\mathrm{C}_{\mathrm{org}}: \mathrm{N}_{\text {tot }}$ ratio from $16.51 \pm$ 0.98 (in 2013) to 13.74 (in 2016).

In 2013, the amounts of phosphorus $\left(\mathrm{P}_{2} \mathrm{O}_{5}\right)$ and potassium $\left(\mathrm{K}_{2} \mathrm{O}\right)$ at the experimental site were $59.3 \pm 13.6$ and $277 \pm 0.02 \mathrm{mg} \mathrm{kg}^{-1}$, respectively, indicating that soil reserves were low. On the contrary, potassium concentration in the upper soil layer was sufficient. In 2016, at the end of the growing rotation, mobile $\mathrm{P}_{2} \mathrm{O}_{5}$ content in the topsoil sharply increased to $332-816 \mathrm{mg} \mathrm{kg}^{-1}$ (significant at the $99 \%$ probability level). Meanwhile, at the end of the field experiment study, mobile $\mathrm{K}_{2} \mathrm{O}$ content in the upper soil layer remained largely unchanged.

\subsection{Soil Aggregate Composition and Aggregate Stability}

The obtained research data revealed that during the research period the majority $(66-73 \%)$ of aggregates in the moraine loam soil were composed of agronomically and ecologically valuable mesoaggregates $(0.25-5 \mathrm{~mm})$ (Table 3$)$. 
Table 3. Soil aggregate composition and the amount of water-stable aggregates in the growing site of common osier dependent on fertilization type in 2015 and 2017.

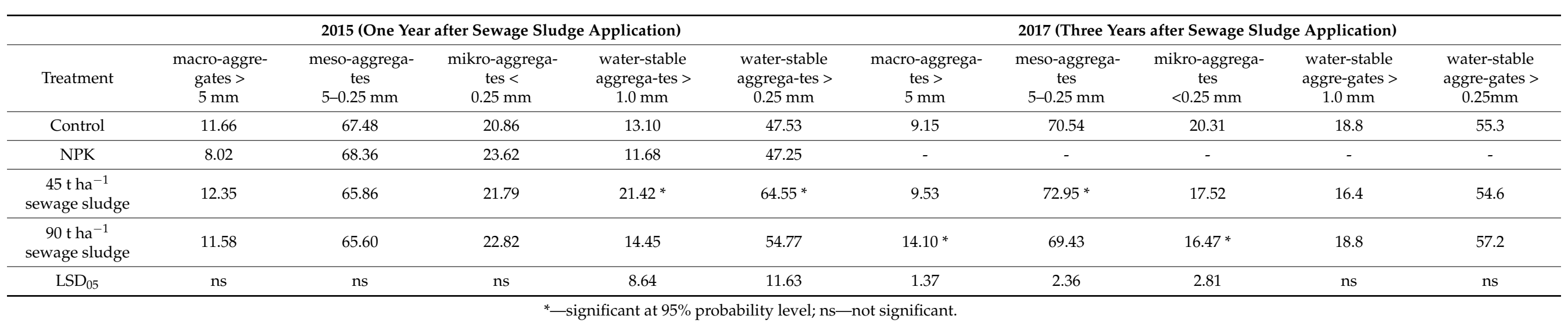


The amount of these aggregates varied slightly from year to year, depending on climatic conditions and fertilization. In 2017, the share of mesoaggregates was $4 \%$ higher than in 2015. Compared to the unfertilized soil (i.e., the control), the most valuable mesoaggregates were formed in the common osier growing site three years after the application of the lower sewage sludge rate $\left(45 \mathrm{tha}^{-1}\right)$. Sewage sludge had a positive effect not only on the formation of aggregates of different sizes but also on their stability. One year after $45 \mathrm{tha}^{-1}$ of sewage sludge application, ecologically valuable water-stable aggregates ( $>1.0 \mathrm{~mm}$ and $>0.25 \mathrm{~mm}$ ) accounted for 21.4 and $64.6 \%$, respectively.

In comparison to the unfertilized soil (i.e., the control treatment), the application of 45 and $90 \mathrm{t} \mathrm{ha}^{-1}$ increased the amount of water-stable aggregates by 38 and $26 \%$, respectively; and by $45 \%$ and $26 \%$ in comparison to NPK application. In 2017, three years after the application of sewage sludge $\left(45 \mathrm{t} \mathrm{ha}^{-1}\right)$, the amount of water-resistant aggregates in the soil ( $>1.0 \mathrm{~mm}$ and $>0.25 \mathrm{~mm}$ ) was 5 and $10 \%$ lower, respectively, than those determined one year after the application of sludge. This indicates that sewage sludge did not have a long-lasting effect on the stability of aggregates.

According to the average data of 2015 and 2017, in the soil where sewage sludge was used for fertilization, the water-stable aggregates was $9-16 \%(>0.25 \mathrm{~mm})$ and $4-18 \%$ $(>1.0 \mathrm{~mm})$ higher compared to the soil in which the sewage sludge was not applied (Control) (Figure 1).

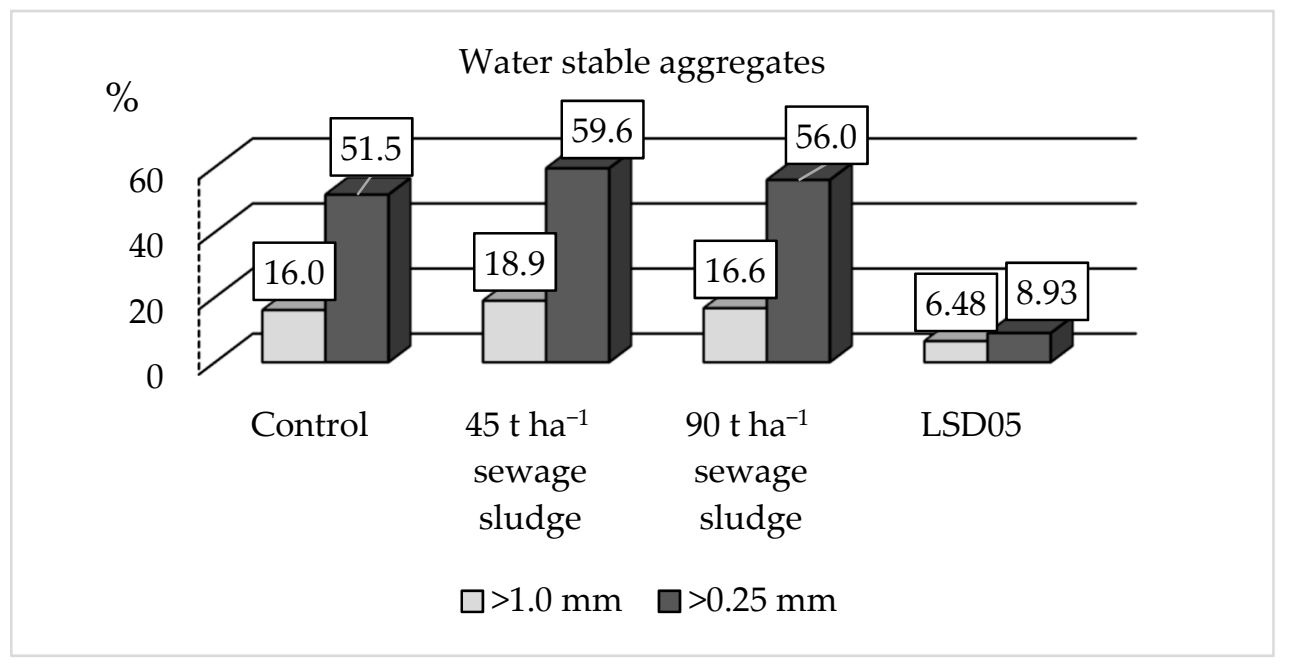

Figure 1. The dependence of soil water-stable aggregates on the fertilization type at the common osier growing site. Average data for 2015 and 2017.

\subsection{Soil Bulk Density and Moisture}

During the study period, in the common osier growing site, soil bulk density values fluctuated in the range of $1.19-1.32 \mathrm{Mg} \mathrm{m}^{-3}$ (Table 4).

The lowest bulk density value was determined in the soil where the lower rate of sewage sludge $\left(45 \mathrm{tha}^{-1}\right)$ was applied. Sewage sludge substantially reduced soil bulk density. On average, the soil bulk density was $6.0-7.5 \%$ lower compared to unfertilized soil (i.e., the control). The application of sewage sludge (especially its highest $90 \mathrm{tha}^{-1}$ rate) caused a higher accumulation of soil moisture (by 11.2\%) than the control treatment (without fertilization). Compared to soil fertilized with mineral fertilizers, fertilization with organic fertilizers (sewage sludge) accumulated a higher amount of organic carbon in the soil. It was a result of higher organic $C$ content and moisture content in the soil applied by sewage sludge. 
Table 4. Soil bulk density and moisture in relation to fertilization type at the common osier growing site in 2015 and 2017.

\begin{tabular}{|c|c|c|c|c|c|c|}
\hline \multirow{2}{*}{ Treatment } & \multicolumn{2}{|c|}{$\begin{array}{c}2015 \text { (One Year after } \\
\text { Sewage Sludge } \\
\text { Application) }\end{array}$} & \multicolumn{2}{|c|}{$\begin{array}{c}2017 \text { (Three Years after } \\
\text { Sewage Sludge } \\
\text { Application) }\end{array}$} & \multicolumn{2}{|c|}{ Average Per 2015-2017 } \\
\hline & $\begin{array}{c}\text { Bulk } \\
\text { Density } \\
\text { Mg m }^{-3}\end{array}$ & Moisture \% & $\begin{array}{c}\text { Bulk } \\
\text { Density } \\
\text { Mg m }^{-3}\end{array}$ & Moisture \% & $\begin{array}{c}\text { Bulk } \\
\text { Density } \\
\mathrm{Mg} \mathrm{m}^{-3}\end{array}$ & Moisture \% \\
\hline Untreated & 1.32 & 22.13 & 1. 32 & 17.87 & 1.32 & 20.00 \\
\hline NPK & 1.33 & 21.65 & - & - & - & - \\
\hline $\begin{array}{l}45 \mathrm{tha}^{-1} \\
\text { sewage } \\
\text { sludge }\end{array}$ & 1.19 * & 20.56 & 1.28 & $20.42 *$ & $1.24 *$ & 20.49 \\
\hline $\begin{array}{l}90 \mathrm{tha}^{-1} \\
\text { sewage } \\
\text { sludge }\end{array}$ & $1.22 *$ & 23.29 & 1.23 & $21.33^{*}$ & $1.22 *$ & 22.31 \\
\hline $\mathrm{LSD}_{05}$ & 0.09 & ns & 0.09 & 1.90 & 0.60 & ns \\
\hline
\end{tabular}

*_-significant at the $95 \%$ probability level; ns—not significant.

\subsection{Microbial Activity}

The biomass of microorganisms in the soil is expressed as the amount of organic carbon (C) in the biomass, known as microbial biomass carbon $[29,30]$. The results are presented in Table 5.

Table 5. The changes in soil microbial biomass carbon $\left(\mu \mathrm{g} \mathrm{g}^{-1} \mathrm{C}\right)$ in humus horizon $(0-30 \mathrm{~cm}$ depth) at the common osier's site from 2014 to 2016.

\begin{tabular}{|c|c|c|}
\hline \multirow{2}{*}{ Treatments } & \multicolumn{2}{|c|}{ Soil Microbial Biomass Carbon $\left(\mu \mathrm{g} \mathrm{g}^{-1} \mathrm{C}\right)$} \\
\hline & Spring & Autumn \\
\hline & \multicolumn{2}{|c|}{2014} \\
\hline Control & $423.1 \pm 21.7 \mathrm{a}$ & $420.9 \pm 14.7 \mathrm{a}$ \\
\hline $45 \mathrm{t} \mathrm{ha}^{-1}$ sewage sludge & $434.7 \pm 21.7 \mathrm{a}$ & $432.1 \pm 14.5 \mathrm{a}$ \\
\hline $90 \mathrm{t} \mathrm{ha}^{-1}$ sewage sludge & $457.0 \pm 13.5 \mathrm{a}$ & $480.0 \pm 24.0 \mathrm{~b}$ \\
\hline \multirow[t]{2}{*}{ On average per year } & $445.8 \pm 12.7 /$ & $456.1 \pm 14.8$ \\
\hline & \multicolumn{2}{|c|}{2015} \\
\hline Control & $432.4 \pm 18.1 \mathrm{a}$ & $434.4 \pm 19.2 \mathrm{a}$ \\
\hline $45 \mathrm{t} \mathrm{ha}^{-1}$ sewage sludge & $451.2 \pm 12.9 \mathrm{ab}$ & $455.3 \pm 20.7 a$ \\
\hline 90 tha $^{-1}$ sewage sludge & $472.9 \pm 16.1 \mathrm{~b}$ & $492.3 \pm 11.0 \mathrm{~b}$ \\
\hline \multirow[t]{2}{*}{ On average per year } & $462.1 \pm 10.3 /$ & $473.8 \pm 12.2$ \\
\hline & \multicolumn{2}{|c|}{2016} \\
\hline Control & $421.6 \pm 8.0 \mathrm{a}$ & $433.2 \pm 19.9 \mathrm{a}$ \\
\hline $45 \mathrm{t} \mathrm{ha}^{-1}$ sewage sludge & $539.1 \pm 31.4 b$ & $625.2 \pm 22.1 \mathrm{c}$ \\
\hline $90 \mathrm{t} \mathrm{ha}^{-1}$ sewage sludge & $625.3 \pm 20.6 c$ & $625.6 \pm 21.3 c$ \\
\hline On average per year & $582.2 \pm 21.0 /$ & $625.4 \pm 14.9$ \\
\hline
\end{tabular}

Mean values \pm standard deviation. The differences between values by different letters are significant.

To evaluate the soil microbial biomass carbon $\left(\mu \mathrm{g} \mathrm{C} \mathrm{g}^{-1}\right)$, we sampled soil before the application of sewage sludge (at the beginning of May 2014). In autumn 2014, microbial biomass carbon in the $0-30 \mathrm{~cm}$ upper soil layer significantly increased up to $480 \mu \mathrm{g} \mathrm{C} \mathrm{g}{ }^{-1}$ only where the $90 \mathrm{t} \mathrm{ha}^{-1}$ sewage sludge rate was applied. Similar results were obtained in 2015; in comparison to 2014, soil microbial biomass carbon increased slightly (particularly using the $90 \mathrm{tha}^{-1}$ sewage sludge rate). Thus, soil microbial biomass carbon during both the 2014 and 
2015 seasons (both in spring and autumn) increased only slightly. Nevertheless, during the 3rd year of investigation (in 2016), soil microbial biomass carbon increased significantly in both sewage sludge application sites-in autumn, soil microbial biomass carbon in both sites (applied by $45 \mathrm{tha}^{-1}$ and $90 \mathrm{tha}^{-1}$ rates) reached up to $625 \mu \mathrm{g} \mathrm{C} \mathrm{g}{ }^{-1}$. This study showed that the consistent increase in soil microbial biomass during three investigation years could be indicated as a result of the ecophysiological approach of soil microorganisms to adapt to changing soil physical properties and fluctuation of nutrients after sewage sludge application in the common osier's sites.

\section{Discussion}

Our field and laboratory results revealed that other than a substantial increase in common osier dry matter (DM), the single use of sewage sludge had a positive effect on changing the chemical, physical, and microbiological properties in Retisol. Since sewage sludge is an alternative organic matter that contains high amounts of macro- and micronutrients, it might be a successful substitute for mineral fertilization of energy crops and particularly common osier. According to the research data, the use of high $90 \mathrm{tha}^{-1}$ granulated sewage sludge significantly increased plant biomass. Further, N60P60K60 fertilization had a rather weak impact on DM yield. Irrespective of fertilization type, common osier DM yield varied from 49.60 to $77.92 \mathrm{t} \mathrm{ha}^{-1}$ (or 12.4-19.5 $\mathrm{t} \mathrm{ha}^{-1}$ per year). Canadian authors noted that regarding Salix cultivars and the number of growing rotations, the application of sewage sludge caused the dry mass yield to increase from 15 to $22 \mathrm{tha}^{-1}$ per year [31]. Other research data conducted in Denmark showed that the application of very high sewage sludge rates (i.e., increasing $\mathrm{N}$ amount from 120 to $240 \mathrm{~kg} \mathrm{ha}^{-1}$ ) did not have any impact on common osier productivity [32]. Comparing these data with other experimental data in which Salix viminalis was annually fertilized with NPK fertilizers, it could be seen that annual mineral fertilization does not have any advantage over organic sewage sludge [33]. We estimated that the productivity of common osier (cv. "Tordis") depended mainly on the number of stems/plants. Neither branch height nor stems diameter had a reliable correlation with DM yield. Based on the literature data of other authors, it can be observed that common osier growth parameters such as the number of stems/plants, stem diameter, stems height, as well as their correlation with DM yield, depending on genotype, growth location, harvest rotation, and their correlation [34].

The application of sewage sludge had no significant impact on soil $\mathrm{pH}_{\mathrm{KCl}}$. In contrast to our results, other authors emphasized that sewage sludge substantially decreased soil acidity $[35,36]$. Other authors state that there is a direct relevance between soil $\mathrm{pH}$ and calcium carbonate content of sewage sludge [36]. The application of a $90 \mathrm{tha}^{-1}$ sewage sludge rate significantly increased $\mathrm{C}_{\mathrm{org}}, \mathrm{N}_{\text {tot }}$, and mobile $\mathrm{P}_{2} \mathrm{O}_{5}$ content in the $0-30 \mathrm{~cm}$ upper soil layer. Other authors have reported the significant impact of sewage sludge on soil $\mathrm{C}_{\text {org }}$ content and $\mathrm{N}_{\text {tot }}$ content, as well as on the fastening of $\mathrm{C}$ and $\mathrm{N}$ mineralization processes [37-39]. The lower is $\mathrm{C}: \mathrm{N}$ ratio, the more intense are $\mathrm{N}$ mineralization rates in soils $[39,40]$. Since mineral phosphorus resources are a limited resource, sewage sludge is a promising secondary source containing considerable amounts of phosphorus [41,42].

Water aggregate stability is considered an important indicator of soil physical quality, as it impacts soil functions such as soil aeration, the movement and storage of soil water, soil erodibility, and carbon sequestration. Soil aggregate stability is an important aspect of soil ecological services and health $[36,43]$. Fertilization with an organic amendment including sewage sludge could potentially alert soil physical properties and thereby affect aggregate stability [8,9]. According to our results, both 45 and $90 \mathrm{tha}^{-1}$ sewage sludge rates had a positive impact on increasing water-stable aggregates and decreasing soil bulk density. The effect of mineral fertilization on soil quality was insignificant.

Changes in microbial biomass carbon indicated that the increase in microbial carbon was not only due to the providing of the high content of available nutrients in sewage sludge but also due to the intensified rooting system of energy crops that could potentially stimulate microbial biomass increment [44-46]. 
An increase in soil microbial biomass carbon indicated that microbial activity could indirectly depend on sewage sludge application but either effected by intensified rooting of the energy crops with potential stimulation of microbial biomass increment

Although the $90 \mathrm{t} \mathrm{ha}^{-1}$ sewage sludge rate had a significant impact on DM productivity and soil chemical content, the parallel experiments indicated that sewage sludge might be energetically and environmentally inexpedient $[7,47]$. Thus, to improve soil qualitative parameters and obtain a high common osier DM yield, the application of $45 \mathrm{tha}^{-1}$ single sewage sludge rate might be sufficient.

Not only from the point of view of plant productivity and soil quality but also from the economic point of view, sewage sludge is a cost-effective organic matter, therefore it is superior to more costly mineral fertilization.

The positive effects of single sewage sludge application on common osier productivity and soil qualitative parameters should remain in the future growing seasons. The most important disadvantage of sewage sludge is its high concentration of heavy metals. We will soon publish another article detailing the dynamics of heavy metal concentration in soil (or its decontamination process) in Salix viminalis biomass during the experimental period. Further, field and laboratory experiments are continuing until 2022.

\section{Conclusions}

The studies conducted in naturally acid Retisol revealed that the single application of sewage sludge had a significant impact on plant and soil productivity. The use of $90 \mathrm{tha}^{-1}$ sewage sludge rate had the highest impact on common osier (Salix viminalis L.) dry matter (DM) yield per four years growing rotation. By contrast, the effect of annual mineral fertilizers on DM yield was significantly inferior. As concerning soil parameters, the use of sewage sludge did not change soil $\mathrm{pH}_{\mathrm{KCl}}$ level, whereas the application of $90 \mathrm{tha}^{-1}$ rate significantly increased organic $\mathrm{C}$, total $\mathrm{N}$, and mobile $\mathrm{P}_{2} \mathrm{O}_{5}$ content in the upper $0-30 \mathrm{~cm}$ soil layer over three years of research. Irrespective of sewage sludge application rate, the amount of water-stable aggregates increased, while soil bunk density tended to decrease. It was estimated that the significantly higher microbial biomass carbon content in soil was indicated only in the third year after sewage sludge application. This alteration showed that sewage sludge amendment effect on soil microbial biomass was prolonged and positive with stimulated soil microbial adaptation.

Author Contributions: Conceptualization, G.Š., D.K., and J.A.; methodology, G.Š., D.K., J.A., and R.S.; software, G.Š., D.K., J.A., and R.R.; data curation, G.Š. and D.K.; writing-review and editing, G.Š., D.K., J.A., R.R. and R.S.; supervision, G.Š. and D.K. All authors have read and agreed to the published version of the manuscript.

Funding: This research received no external funding.

Informed Consent Statement: Informed consent was obtained from all subjects involved in the study.

Data Availability Statement: The data presented in this study are available within the article.

Acknowledgments: The study was conducted in compliance with the long-term program "Plant biopotential and quality for multifunctional practice".

Conflicts of Interest: The authors declare no conflict of interest.

\section{References}

1. Kocik, A.; Truchan, M.; Rozen, A. Application of willows (Salix viminalis) and earthworms (Eisenia fetida) in sewage sludge treatment. Eur. J. Soil Biol. 2007, 43, 327-331. [CrossRef]

2. Charlton, A.; Sakrabani, R.; Tyrrel, S.; Casado, M.R.; McGrath, S.P.; Crooks, B.; Campbell, C.D. Long-term impact of sewage sludge application on soil microbial biomass: An evaluation using meta-analysis. Environ. Pollut. 2016, 219, 1021-1035. [CrossRef] [PubMed]

3. Kirchmann, H.; Börjesson, G.; Kätterer, T.; Cohen, Y. From agricultural use of sewage sludge to nutrient extraction: A soil science outlook. Ambio 2017, 46, 143-154. [CrossRef] [PubMed] 
4. Leila, S.; Mhamed, M.; Hermann, H.; Mykola, K.; Oliver, W.; Christin, M.; Onyshchenko, E.; Bouchenaha, N. Fertilization value of municipal sewage sludge for Eucalyptus camaldulensis plants. Biotechnol. Rep. 2017, 13, 8-12.

5. Singh, R.P.; Agrawal, M. Potential benefits and risks of land application of sewage sludge. Waste Manag. 2008, 28, 347-358. [CrossRef]

6. Lederer, J.; Rechberger, H. Comparative goal-oriented assessment of conventional and alternative sewage sludge treatment options. Waste Manag. 2010, 30, 1043-1056.

7. Šiaudinis, G.; Karčauskienè, D.; Aleinikovienè, J. Assessment of a single application of sewage sludge on the biomass yield of Silphium perfoliatum and changes in naturally acid soil properties. Zemdirb. Agric. Akad. 2019, 106, $213-218$.

8. Börjesson, G.; Kätterer, T. Soil fertility effects of repeated application of sewage sludge in two 30-year-old field experiments. Nutr. Cycl. Agroecosyst. 2018, 112, 369-385. [CrossRef]

9. Haydu-Haudeshell, C.A.; Graham, R.C.; Hendrix, P.F.; Peterson, A.C. Soil aggregate stability under chaparral species in Southen California. Geoderma 2018, 310, 201-208. [CrossRef]

10. Zoghlami, R.I.; Hamdi, H.; Mokni-Tlili, S.; Hechmi, S.; Khelil, M.N.; Aissa, N.B.; Moussa, M.; Bousnina, H.; Benzarti, S.; Jedidi, N. Monitoring the variation of soil quality with sewage sludge application rates in absence of rhizosphere effect. Int. Soil Water Conserv. Res. 2020, 8, 245-252. [CrossRef]

11. Buonocore, E.; Mellino, S.; De Angelis, G.; Liu, G.; Cooper, P.; Ulgiati, S. Life cycle assessment indicators of urban wastewater and sewage sludge treatment. Ecol. Indic. 2018, 94, 13-23. [CrossRef]

12. Urbaniak, M.; Toloczko, W.; Serwecinska, L.; Wyrwicka, A. The effect of sewage sludge application on soil properties and wilow (Salix sp.) cultivation. Sci. Total Environ. 2017, 586, 66-75. [CrossRef] [PubMed]

13. Usman, K.; Khan, S.; Ghulam, S.; Khan, M.U.; Khan, N.; Khan, M.A.; Khalil, S.K. Sewage sludge: An important biological resource for sustainable agriculture and its environmental implications. Am. J. Plant Sci. 2012, 3, 1708-1721. [CrossRef]

14. Iglesias, M.; Marguí, E.; Camps, F.; Hidalgo, M. Extractability and crop transfer of potentially toxic elements from Mediterranean agricultural soils following long-term sewage sludge applications as a fertilizer replacement to barley and maize crops. Waste Manag. 2018, 75, 312-318. [CrossRef] [PubMed]

15. Jarausch-Wehrheim, B.; Mocquot, B.; Mench, M. Absorption and translocation of sludge-borne zinc in field-grown maize (Zea mays L.). Eur. J. Agron. 1999, 11, 23-33. [CrossRef]

16. McGrath, S.P.; Zhao, F.J.; Dunham, S.J.; Crosland, A.R.; Coleman, K. Long-term changes in extractability and bioavailability of zinc and cadmium after sludge application. J. Environ. Qual. 2000, 29, 875-883. [CrossRef]

17. Žaltauskaitè, J.; Judeikytè, S.; Sujetovienè, G.; Dagiliūtè, R. Sewage sludge application effects to first year willows (Salix viminalis L.) growth and heavy metal bioaccumulation. Waste Biomass Valoriz. 2017, 8, 1813-1818. [CrossRef]

18. Dickinson, N.M.; Pulford, I.D. Cadmium phytoextraction using short-rotation coppice Salix: The evidence trail. Environ. Int. 2005, 31, 609-613. [CrossRef]

19. Brandao, M.; i Canals, L.M.; Clift, R. Soil organic carbon changes in the cultivation of energy crops: Implications for GHG balances and soil quality for use in LCA. Biomass Bioenergy 2010, 35, 2323-2336.

20. Richards, B.K.; Stoof, C.R.; Cary, I.J.; Woodbury, P.B. Reporting on marginal lands for bioenergy feedstock production: A modest proposal. Bioenergy Res. 2014, 7, 1060-1062. [CrossRef]

21. Nilsson, D.; Rosenqvist, H.; Bernesson, S. Profitability of the production of energy grasses on marginal agricultural land in Sweden. Biomass Bioenergy 2015, 83, 159-168. [CrossRef]

22. Kuzovkina, Y.A.; Schulthess, C.P.; Zheng, D. Influence of soil chemical and physical characteristics on willow yield in Connecticut. Biomass Bioenergy 2018, 108, 297-306.

23. Mažvila, J.; Adomaitis, T.; Eitmanavičius, L. Changes in the acidity of Lithuania's soils as affected of not liming. Agriculture 2004, 4, 3-20. (In Lithuanian)

24. Herr, J.R. Bioenergy from trees. New Phytol. 2011, 192, 313-315. [CrossRef] [PubMed]

25. Karp, A.; Hanley, S.J.; Trybush, S.O.; Macalpine, W.; Pei, M.; Shield, I. Genetic improvement of willow for bioenergy and biofuels free access. J. Integr. Plant Biol. 2011, 53, 151-165. [PubMed]

26. Vadiunina, A.P.; Korchagina, Z.A. Methods for Determining the Physical Properties of the Soil, 3rd ed.; Mosc. Agropromizdat: Moscow, Russian, 1986; pp. 53-79. (In Russian)

27. Vance, E.D.; Brookes, P.C.; Jenkinson, D.S. An extraction method for measuring soil microbial biomass C. Soil Biol. Biochem. 1987, 19, 703-707. [CrossRef]

28. Alriksson, B.; Ledin, S.; Seeger, P. Effect of nitrogen fertilization on growth in a Salix viminalis stand using a response surface experimental design. Scand. J. For. Res. 1997, 12, 321-327. [CrossRef]

29. Kasel, S.; Bennett, L.T. Land-use history, forest conversion, and soil organic carbon in pine plantations and native forests of south eastern Australia. Geoderma 2007, 137, 401-413. [CrossRef]

30. Zhang, J.; Bei, S.; Li, B.; Zhang, J.; Christie, P.; Li, X. Organic fertilizer, but not heavy liming, enhances banana biomass, increases soil organic carbon and modifies soil microbiota. Appl. Soil Ecol. 2019, 136, 67-79. [CrossRef]

31. Nissim, W.G.; Pitre, F.E.; Teodorescu, T.I.; Labrecque, M. Long-term biomass productivity of willow bioenergy plantations maintained in southern Quebec, Canada. Biomass Bioenergy 2013, 56, 361-369. [CrossRef]

32. Sevel, L.; Nord-Larsen, T.; Ingerslev, M.; Jørgensen, U.; Raulund-Rasmussen, K. Fertilization of SRC willow, I: Biomass production response. BioEnergy Res. 2014, 7, 319-328. [CrossRef] 
33. Šiaudinis, G.; Jasinskas, A.; Karčauskienè, D.; Repšienè, R. The effect of liming and nitrogen application on common osier and black poplar biomass productivity and determination of biofuel quality indicators. Renew. Energy 2020, 152, 1035-1040.

34. Stolarski, M.J.; Krzyżaniak, M.; Załuski, D.; Tworkowski, J.; Szczukowski, S. Effects of Site, Genotype and Subsequent Harvest Rotation on Willow Productivity. Agriculture 2020, 10, 412. [CrossRef]

35. Neilsen, G.H.; Hogue, E.J.; Neilsen, D.; Zebarth, B.J. Evaluation of organic wastes as soil amendments for cultivation of carrot and chard on irrigated sandy soils. Can. J. Soil Sci. 1998, 78, 217-225. [CrossRef]

36. Eitminavičiūtè, I.; Matusevičiūtè, A.; Gasiūnas, V.; Radžiūtè, M.; Grendienè, N. Ecotoxicological assessment of arable field soils fertilized with sewage sludge. Ekologija 2009, 55, 142-152. [CrossRef]

37. Sommers, L.E. Chemical composition of sewage sludges and analysis of their potential use as fertilizers. J. Environ. Qual. 1977, 62, 225-232.

38. Hemmat, A.; Aghilinategh, N.; Rezainejad, Y.; Sadeghi, M. Long-term impacts of municipal solid waste compost, sewage sludge and farmyard manure application on organic carbon, bulk density and consistency limits of a calcareous soil in central Iran. Soil Tillage Res. 2010, 108, 43-50. [CrossRef]

39. Huang, C.C.; Chen, Z.S. Carbon and nitrogen mineralization of sewage sludge compost in soils with a different initial pH. Soil Sci. Plant Nutr. 2009, 55, 715-724.

40. Roig, N.; Sierra, J.; Martí, E.; Nadal, M.; Schuhmacher, M.; Domingo, J.L. Long-term amendment of Spanish soils with sewage sludge: Effects on soil functioning. Agric. Ecosyst. Environ. 2012, 158, 41-48. [CrossRef]

41. Andriamananjara, A.; Rabeharisoa, L.; Prud'homme, L.; Morel, C. Drivers of plant-availability of phosphorus from thermally conditioned sewage sludge as assessed by isotopic labeling. Front. Nutr. 2016, 3, 19. [CrossRef]

42. Semerci, N.; Kunt, B.; Calli, B. Phosphorus recovery from sewage sludge ash with bioleaching and electrodialysis. Int. Biodeterior. Biodegrad. 2019, 144, 104739. [CrossRef]

43. Toosi, E.R.; Kravchenko, A.N.; Mao, J.; Quigley, M.Y.; Rivers, M.L. Effects of management and pore characteristics on organic matter composition of macroaggregates: Evidence from characterization of organic matter and imaging. Eur. J. Soil Sci. 2017, 68, 200-211. [CrossRef]

44. Martins, T.; Saab, S.D.C.; Milori, D.M.B.P.; Brinatti, A.M.; Rosa, J.A.; Cassaro, F.A.M.; Pires, L.F. Soil organic matter humification under different tillage managements evaluated by Laser Induced Fluorescence (LIF) and C/N ratio. Soil Tillage Res. 2011, 111, 231-235. [CrossRef]

45. Shahzad, T.; Rashid, M.I.; Maire, V.; Barot, S.; Perveen, N.; Alvarez, G.; Mougin, C.; Fontaine, S. Root penetration in deep soil layers stimulates mineralization of millennia-old organic carbon. Soil Biol. Biochem. 2018, 124, 150-160. [CrossRef]

46. Brust, G.E. Management strategies for organic vegetable fertility. In Safety and Practice for Organic Food; Academic Press: Cambridge, MA, USA, 2019; pp. 193-212.

47. Šiaudinis, G.; Karčauskienè, D. The effect of sewage sludge on and cup plant's (Silphium perfoliatum L.) biomass productivity under Western Lithuania's Retisol. In Proceedings of the International Scientific Conference "Rural Development", Kaunas, Lithuania, 23-24 November 2017; pp. 148-152. 